\title{
MENGAPA ALLAH MEMAKAI DWIGHT LYMAN MOODY? Kisah Hidup Seorang Pelayan Sekolah Minggu
}

\author{
Hengki Wijaya ${ }^{1}$ \\ sttjaffraymakassar@yahoo.co.id \\ hengki_lily@yahoo.com
}

\section{PENDAHULUAN}

Dalam pemeliharaan Allah yang kekal dan berdaulat, Allah telah memilih untuk memakai orang-orang biasa, yang diberi kuasa Roh Kudus yang luar biasa, sebagai sarana utama yang melaluinya Dia menyebarkan kebenaran firman-Nya. Melalui perjalanan hidup Dwight Lyman Moody, penulis mengajak pembaca untuk mempelajari kunci keberhasilan pelayanan dan kehidupan rumah tangga bersama anakanaknya yang dapat berjalan seimbang ditengah-tengah kesibukan melayani Tuhan.

Seorang pelayan Sekolah Minggu yang terus mengundang orang berdosa untuk datang kepada Kristus sampai akhir hidupnya adalah sesuatu yang menarik untuk diketahui bagaimana falsafah pelayanannya yang menyebabkan Allah memakai D.L. Moody dengan sangat luar biasa. Untuk hal tersebut maka penulis menuliskan suatu riwayat hidup D.L. Moody, seorang pelayan Sekolah Minggu.

\section{A. Riwayat Hidup Dwight Lyman Moody (1837-1899)}

Dwight Lyman Moody dilahirkan pada tanggal 5 Februari 1837 di Northfield Massachusetts. Dia baru saja berusia empat tahun saat ayahnya, seorang tukang batu bata, meninggal. Ditinggalkan bersama sembilan orang anak yang masih berusia di bawah tiga belas tahun, Betsey Moody sepenuhnya berkewajiban untuk memberi makan dan pakaian, serta membesarkan anak-anaknya yang amat banyak. Akibatnya, pendidikan yang diperoleh Dwight mungkin hanya setara dengan pendidikan hingga kelas lima Sekolah Dasar zaman sekarang. ${ }^{2}$

Pada usia sangat muda, Dwight mencari uang sendiri pada musim panas. Pekerjaan pertamanya adalah menggembalakan sapi-sapi milik

\footnotetext{
${ }^{1}$ Mahasiswa Program Pascasarjana yang mengambil Mata Kuliah Filsafat Pelayanan. Dwight Lyman Moody adalah salah satu tokoh Kebangunan Rohani abad ke-19 dan masa dimana A.B. Simpson juga dipakai oleh Allah.

${ }^{2}$ Dave dan Neta Jackson. Bahaya di Ujung Tali Akrobat. Batam: Gospel Press, 2004, 169 diakses 25 November 2011 dari http://biokristi.sabda.org/dwight_l_moody
} 
tetangganya ke padang rumput. Upahnya satu sen sehari. Moody kecil tidak terlalu berminat terhadap masalah agama, tetapi ibunya, Betsey, selalu tekun mengajar anak-anaknya untuk berdoa dan menepati janji. Pada masa kecilnya tidak ada tanda atau peristiwa yang menunjukkan bahwa Moody akan dapat berbuat sedemikian mengagumkan dalam pelayanan misi di kemudian hari. ${ }^{3}$

Keinginan terbesar Dwight muda adalah pergi dari kota kecil Northfield dan menjadi orang kaya. Dia meninggalkan rumah saat berusia tujuh belas tahun untuk bekerja pada pamannya di Boston sebagai pedagang sepatu. Dwight diminta menghadiri gereja dan Sekolah Minggu yang termasuk dalam kesepakatan kerja dengan pamannya. Ini menjadi kewajiban yang membosankan sampai ia ditempatkan di kelas yang dipimpin oleh seorang laki-laki saleh bernama Edward Kimball, yang menunjukkan kebaikan dan kasih yang membuat dia begitu perhatian di kelas itu. ${ }^{4}$

Pada tanggal 21 April 1855, Kimball merasakan bahwa sudah waktunya menganjurkan Dwight L. Moody berjanji kepada Kristus. Ia menuju ke toko sepatu, berubah pikiran, dan jalan melewati toko itu, kemudian kembali terburu-buru, serta masuk ke toko itu. Ia menemukan Moody sedang membungkus dan menyemir sepatu. Orang muda itu sudah siap mendengarkannya. ${ }^{5}$ Kimball secara khusus membentangkan kasih Kristus kepadanya dan pengorbanan Kristus untuk keselamatannya. Moody tiba-tiba siap untuk menerima Kristus dan seperti yang sering terjadi, ia melihat Kristus menempatkan segala sesuatu dalam perspektif baru. Moody berkata ${ }^{6}$ :

"Pagi ketika bertobat, saya pergi ke luar rumah dan merasa jatuh cinta kepada apa saja. Saya tidak pernah mengasihi matahari yang menyinari bumi seperti itu sebelumnya. Ketika mendengar burung-burung berkicau dengan indahnya, saya merasa jatuh cinta kepada burung-burung itu. Segala sesuatunya menjadi berbeda."

Dwight senang bekerja sebagai penjual sepatu. Dia mempunyai keahlian alami dalam berdagang. Namun, Boston terlalu sesak bagi dirinya. Pada tahun 1856, saat dia berusia dua puluh tahun, Dwight pergi ke barat menuju Chicago tempat dia bekerja bagi C. E. Wisall, seorang pengusaha sepatu. Kali ini dia berambisi untuk mengumpulkan uang

\footnotetext{
${ }^{3}$ D.L . Moody. Secret of Power. Yogyakarta: Penerbit ANDI, 2010, 4.

${ }^{4}$ Moody, 5.

${ }^{4}$ A. Kenneth Curtis et al. 100 Peristiwa Penting dalam Sejarah Kristen. Jakarta: BPK Gunung Mulia, 2009, 139.

${ }^{6}$ Moody, 5.
} 
sebanyak 100.000 dolar. Beberapa tahun kemudian, Dwight berkeliling Midwest untuk memperkenalkan sepatu Wisell, tetapi dia selalu kembali ke Chicago untuk mengantar anak-anak mengikuti misi sekolah minggu, akhirnya jumlah anak-anak itu dapat mencapai lebih dari seribu orang. Dia ikut berperan dalam mengurus sekolah minggu itu. ${ }^{7}$

Salah seorang pekerja sekolah minggu, Emma Revell, menarik perhatian Moody. Dia mengumumkan pertunangannya dengan Emma, yang baru berusia enam belas tahun dengan pernyataan sederhana bahwa dirinya "tidak akan bersedia lagi untuk mengawal wanita muda lain pulang ke rumah"! $!^{8}$

Moody muda menyadari minimnya pendidikan dan pengetahuan Alkitab yang dimilikinya sehingga dia merasa tidak dapat memenuhi syarat untuk menjadi seorang guru. Tetapi saat dirinya diminta untuk membantu pelayanan kunjungan ke rumah-rumah, Moody dengan enggan menemani seorang guru sakit-sakitan bernama Hibbert yang ingin memenangkan jiwa setiap murid putri di kelasnya bagi Kristus sebelum dirinya meninggal. Pertobatan dan kembalinya "anak-anak perempuan kumuh" ini bagi Kristus berpengaruh besar dalam diri Moody sehingga dia berhenti menjual sepatu dengan tujuan "bekerja sepenuhnya bagi pelayanan Kristen". ${ }^{\text {. }}$

The Young Man's Christian Association (YMCA) menunjuk Moody sebagai misionaris. Selama masa Perang Sipil, dia menjadi pendeta YMCA yang ditempatkan di pos tentara dekat Chicago. (Moody tidak ikut serta menjadi tentara karena dia berpendapat bahwa merampas hidup orang lain merupakan tindakan yang salah). Di tengah masa perang, dia menikahi Emma Revell (saat itu berusia dua puluh tahun) dan dua tahun kemudian mereka mendapatkan seorang putri, yang juga diberi nama Emma. ${ }^{10}$

Tahun 1867, Moody menghabiskan waktu empat bulan untuk berkunjung dan berbicara di YMCA Inggris. Saat berada di Inggris, dia bertemu dengan dua orang yang beriman teguh, Charles Spurgeon dan George Muller. Dia juga bertemu dengan Pendeta Henry Varley, yang menantang Moody dengan perkataan, "Dunia ini belum melihat tindakan yang dapat Tuhan lakukan melalui seorang pria yang sepenuhnya mengabdi kepada-Nya." Kata-kata ini sangat memengaruhi Moody sehingga dia berjanji untuk menjadi pria seperti itu. ${ }^{11}$ Pada tahun 1870 , pada Pertemuan Internasional YMCA, dia mendengar nyanyian seorang

${ }^{7}$ Dave dan Neta J., 170.

${ }^{8}$ Ibid., 171.

8 Dave dan Neta J., hal. 172.

${ }^{10}$ Ibid., 173.

11 Ibid. 
penyanyi lagu pujian yang bernyanyi dengan suara amat mengesankan. Dia mengajak Ira Sankey untuk bergabung dengan dirinya dan menjadi pemimpin musik; selama dua dekade selanjutnya "Moody dan Sankey" menjadi terkenal sebagai tim pengabar Injil dunia. ${ }^{12}$

Pada tanggal 8 Oktober 1871, Kebakaran Besar Chicago menghancurkan rumah baru Moody, Aula Farwell YMCA yang didirikan atas bantuan Moody, dan Gereja Jalan Illinois. Awalnya dia merasa terguncang, tetapi kemudian Moody segera menyadari bahwa tumbangnya pelayanan organisasinya di Chicago sebagai sebuah kesempatan untuk terjun sepenuhnya dalam pelayanan pengabaran Injil. ${ }^{13}$

Pada tahun 1879, Moody mengalihkan perhatiannya kepada pendidikan dengan mendirikan Northfield Seminary bagi para gadis dan kemudian Mount Hermon School bagi anak-anak lelaki. Ia memulai konferensi-konferensi Alkitab musim panas dan sebuah institute Alkitab yang sekarang memakai namanya. Ia melihat kebutuhan yang lebih besar untuk latihan-latihan praktik pelayanan. Ia bermaksud melatih para komunikator yang akan membawa firman Allah yang sederhana kepada mereka yang membutuhkan. ${ }^{14}$

Pada tahun 1882, Moody kembali ke London untuk mengadakan kebaktian berikutnya. Sesudah kembali, ia pergi lagi untuk bekerja di Amerika mengadakan kebaktian kebangunan rohani besar-besaran pada akhir tahun 1880-an dan awal 1890-an. Denver, San Francisco, Richmond, Hartford, Providence dan banyak kota yang lainnya ditambahkan ke daftar kota-kota yang digarap oleh penginjil yang tidak kenal lelah itu. ${ }^{15}$

Riwayat singkat D.L. Moody dirumuskan sebagai berikut:

"Pada suatu hari saudara akan membaca di surat kabar, bahwa D.L. Moody dari East Northfield meninggal dunia. Pada saat ini saya akan lebih bahagia daripada sekarang. Saya pindak ke alam baka saja; pindah dari bumi ke rumah yang kekal, suatu tubuh yang tahan maut, yang tak dapat dinodai oleh dosa, suatu tubuh yang serupa dengan tubuh-Nya yang mulia itu. Saya dilahirkan secara

\footnotetext{
${ }^{12}$ Moody, 13-14.

13 Curtis, 139.

14 Curtis, 139-140.

15 Moody, 23.
} 
jasmani pada tahun 1837. Saya dilahirkan secara rohani pada tahun 1855. Yang dilahirkan secara jasmani boleh mati. Yang diperanakkan secara rohani akan hidup selama-lamanya". ${ }^{16}$

\section{B. Keberhasilan Pelayanan D.L. Moody}

D.L. Moody pindah ke Chicago, mencari kesempatan di daerah yang disebut Barat, Boston terlalu sempit dan ambisinya mengarahkannya ke padang rumput yang terbentang luas. Pada hari Minggu pertamanya di Chicago, ia pergi ke Sekolah Minggu Gereja Baptis Pertama, dimana calon istrinya kelak hadir juga ketika masih remaja. Ia mulai menghadiri Plymouth Congregational Church dan segera semangat untuk memberitakan Kristus berkobar di hatinya. Ia melihat banyak pemuda kesepian yang tidak pergi ke gereja, khususnya ketika gereja-gereja begitu padat pengunjung. Jadi ia menyewa empat baris bangku dan pergi mengundang orang-orang untuk duduk bersamanya. Usahanya itu segera menunjukkan hasil. ${ }^{17}$

Ia juga bergabung dengan Young Men's Mission Band, membagibagikan traktat dan mengundang orang-orang ke gereja. Pada Minggu sore, ia pergi ke sebuah Sekolah Minggu kecil. Dengan pendidikan yang sedemikin terbata, ia berhasil lulus kelas setara dengan kelas lima. Ia tidak mempunyai keinginan mengajar hingga merasa seharusnya ia mengajar satu kelas. Pengawasnya mengatakan bahwa mereka sudah mempunyai cukup guru, tetapi kekurangan murid. Minggu berikutnya, Moody datang bersama 18 pemuda dari jalanan yang melipatgandakan jumlah murid di kelas itu. Kemudian ia mulai mengajar mereka sedikit hal yang diketahuinya pada waktu itu, dan mendesak mereka untuk menerima Kristus. ${ }^{18}$

Pada musim gugur 1858, ia memulai kelas Sekolah Minggunya sendiri di sebuah warung minum yang kosong, dengan sasaran utama anak-anak jalanan. Ia mempunyai hati yang lembut untuk memahami kehidupan keras anak-anak dan pemuda yatim. Dalam waktu singkat, ia dapat menyewa sebuah gedung yang lebih besar, sementara orang-orang muda tertarik kepada kepada berita tentang Kristus yang disampaikannya dengan sederhana, tetapi menyentuh hati. Walikota bahkan mengakui usahanya dan menyediakan aula yang tadinya dipakai untuk menari dan merokok setiap malam Minggu, Moody, hamba Allah yang taat itu, datang ke aula itu beberapa jam sebelumnya dan menyapu

16 A.P. Fitt. Riwayat Hidup D.L. Moody. Surabaya:Christian Literature Crusade, 2008 diakses 25 November 2011 dari http://www.sabda.org/misi/tokoh_isi.php?id=7

${ }^{17}$ Moody, 6.

${ }^{18}$ Ibid, 6-7. 
puntung rokok serta sampah lain dan menyiapkan ruangan itu untuk Sekolah Minggu. Selain itu, ia juga tidak malu-malu pergi ke rumahrumah untuk memberitakan kebenaran. ${ }^{19}$

Pada tahun 1864 didirikan Illinois Street Church untuk Sekolah Minggu dan kebaktian. Gereja itu menampung 1.500 orang. Moody berkhotbah tiap Minggu pagi dan mengajar 1.000 murid pada Minggu sore. Sesuai dengan sifatnya yang rendah hati, Moody hanya menjadi salah seorang diaken di gereja itu. Ia menghindari semua gelar, bahkan "pendeta", dan hanya mau dipanggil "Bapak Moody tua". Dalam beberapa bulan, karena kesetiaannya,pekerjaaan yang tekun itu diberkati Tuhan. Kelas-kelas Sekolah Minggu itu dihadiri oleh 1.500 orang, dan hamba Allah yang masih muda, tidak dikenal, tidak terpelajar dan tidak pandai bicara ini mulai diakui di kota yang sedang berkembang itu. Akhirnya, Presiden Abraham Lincoln dan Presiden Grant pernah mengunjungi Sekolah-sekolah Minggunya di Chicago. ${ }^{20}$

Moody yang telah membangun Illinois Street Church, membangun juga Farwell Hall. Ia berkeras menamainya sesuai dengan nama sahabat (John Farwell) dan penyokongnya dalam pekerjaan Tuhan. Banunan itu diresmikan pada tahun 1867. Pada upacara pembukaannya, Moody mengatakan bahwa ia percaya pekerjaan menyelamatkan jiwa-jiwa dan menyerang dosabaru saja dimulai. Secara profetik itu benar. Namun, akan ada banyak ujian berat. Empat bulan sesudah Farwell Hall selesai, gedung itu terbakar habis. Kemudian Moody bertekad untuk membangun gedung Farewell Hall dipakai untuk kebaktian besar. Namun, empat tahun kemudian, gedung itu terbakar lagi bersama banyak gedung lain di kota itu dalam kebakaran besar Chicago yang juga melanda gereja dan rumah Moody. Api itu mungkin telah menghancurkan banyak pekerjaannya di Chicago, tetapi Allah memilih mengirim api rohani ke hati Moody dan mengurapi ia untuk api kebangunan rohani di banyak Negara. ${ }^{21}$

Penyertaan Roh Kudus untuk pekerjaan Allah, Moody berangkat ke Inggris bersama Ira Sankey pada tahun 1873, tanpa tahu apa yang akan dilakukan Allah di sana. Tangan Allah menyertai pekerjaan itu. Mereka diterima oleh semua denominasi, kecuali Gereja Anglikan yang sudah mapan. Namun, banyak anggota gereja itu akhirnya menghadiri kebaktian-kebaktian mereka. Jelas bahwa ada gerakan Roh Kudus yang berkuasa, dan koran-koran nasional mulai melaporkan "kebangunan

19 Ibid, 7.

20 Ibid, 11.

21 Ibid, 12. 
rohani” itu. Kuasa Roh Kudus melanda setiap kelas dalam masyarakat, dari aristokrat tertinggi sampai ke anak jalanan yatim piatu yang paling rendah. ${ }^{22}$

Moody menolak mendata jumlah orang yang bertobat. Ia menyatakan bahwa itu bukan tanggung jawabnya. Ketika seorang dokter menanyakan kepadanya tentang berapa banyak orang yang bertobat dalam pelayanannya, ia menjawab dalam gayanya yang tanpa basa-basi: "Saya tidak tahu soal itu, dokter. Puji Tuhan, saya tidak harus mengetahuinya. Bukan saya yang memegang Kitab Kehidupan Anak Domba." Kebangunan rohani besar di Skotlandia bergerak ke Irlandia dengan hasil sama. Kemudian kebangunan itu mengalir ke selatan ke kota-kota besar di Inggris seperti bola salju yang menggelinding menuruni bukit. ${ }^{23}$

Pada tahun 1875, Moody tiba di London untuk mengadakan apa yang nantinya menjadi salah satu kampanye penginjilan yang terbesar dalam sejarah Eropa. Kebaktian-kebaktian diadakan di Agriculture Hall yang dapat menampung 20.000 orang. Namungedung yang sangat besar itu pun tidak cukup menampung orang London yang berjejalan mencari Allah. Beberapa tempat lain, yang menampung sampai 5.000 orang juga digunakan dan padat. Moody bukan lagi sekadar guru Sekolah Minggu Chicago. Pada umur 38 tahun, sesudah dua tahun di Inggris Raya, Allah telah membangkitkan penginjil kelas dunia yang rendah hati dan tiada duanya di sana. Penulis biografi dan teman sezaman Moody, A.P. Fitt, menulis: "Tidak hanya London menjadi heboh, tetapi juga mencengangkan seluruh dunia." ${ }^{24}$

Fitt menulis kesimpulan ini tentang kebangunan rohani yang terjadi di Inggris pada tahun 1873-1875: $:^{25}$

"Ribuan orang yang belum diselamatkan dan ribuan orang Kristen yang mundur dibawa kepada persekutuan yang lebih erat dengan Allah. Semangat penginjilan telah bangkit dan tidak pernah mati lagi. Sejumlah besar misi kota dan organisasin lainnya yang aktif dan agresif didirikan. Perbedaan denominasi dikuburkan. Para rohaniwan dari semua denominasi bekerja sama untuk satu tujuan, yaitu keselamatan orang yang terhilang. Alkitab dibuka kembali, dan pendalaman Alkitab mendapat tanggapan yang baik ... Kehidupan baru meresap dalam setiap metode kegiatan Kristen.

22 Ibid, 15-16.

23 Ibid, 16-17.

24 Ibid,17.

${ }^{25}$ Ibid, 17-18; A.P. Fitt. The Life of D.L. Moody. The Bible Institute Colportage Association,1900. 
Tidak ada usaha untuk menarik orang menjadi anggota gereja tertentu, dan orang-orang yang bertobat menghadiri gereja-gereja yang ada untuk mendapatkan makanan rohani dan nasihat dalam Tuhan."

Moody membawa penginjilan ke zaman industry sambil membangun tradisi revivalis yang didirikan Charles Finney. Ia mengkhotbahkan Injil yang sederhana, bebas dari bermacam-macam denominasi. Hal itu memperbesar daya tarik serta dukungannya. Ia bersekutu dengan para pengusaha. Merekalah para pemimpin generasi baru, bukan para pengkhotbah. Ia menekankan supaya mereka menggunakan harta mereka untuk hal-hal baik seperti peduli kepada orang-orang miskin perkotaan. Moody menerapkan teknik usahanya pada perencanaan penginjilannya. Musik, konseling dan follow-upnya adalah bagian-bagian dari pendekatan terorganisasi untuk mengambil hati orang. ${ }^{26}$

Pada tahun 1879. Moody mengubah kota kecilnya dengan mendirikan Seminari Northfield untuk perempuan muda, Sekolah Mount Hermon untuk laki-laki muda pada tahun 1881, Sekolah Pendidikan untuk perempuan muda pada tahun 1890, dan gudang timur untuk Bible Institution's Association of Chicago pada 1895 (yang kemudian hari menjadi Institut Alkitab Moody). ${ }^{27}$ Moody juga membantu dalam mendirikan dua perusahaan percetakan, yaitu Fleming H. Revell (diberi nama sesuai dengan nama saudara laki-laki Emma, yang menerbitkan banyak khotbah Moody), dan Bible Institute Colportage Association (Asosiasi Kolportase Institut Alkitab (kemudian berubah nama menjadi Moody Press). ${ }^{28}$

Pada tahun 1892, saat berada di atas kapal Spree dalam perjalanan kembali menuju Amerika Serikat bersama anaknya Will, sebuah kecelakaan yang hampir berakibat fatal terjadi di laut. Hal ini mengakibatkan Moody melipatgandakan waktu berkhotbahnya, walaupun dokter telah menasihatinya untuk mengurangi kegiatan. Moody beralasan, waktu sangat singkat! Orang-orang terhilang masih banyak! Bagi dirinya, yang terpenting hanyalah bekerja bagi Kristus. Hal ini membuat dirinya mengadakan kampanye besar selama Pekan Raya

\footnotetext{
${ }^{26}$ Curtis, 139.

27 Moody, 21.

${ }^{28}$ Dave dan Neta, 174.
} 
Sedunia Chicago pada tahun berikutnya, enam bulan lamanya ia berkhotbah dengan menyewa tenda Sirkus Adam Forepaugh. Putra bungsunya, Paul, yang saat itu baru berusia lima belas tahun, menemaninya selama kampanye ini. ${ }^{29}$

Kebaktian penginjilan di Kansas City pada November 1899 menjadi kebaktian penginjilan terakhirnya. Walaupun tiba di kota tersebut dalam keadaan sakit, ia berkhotbah enam kali dalam sehari. Khotbahnya yang terakhir adalah di Kansas, Missouri, di gedung Convention Hall yang berkapasitas 15.000 orang. Ia berkhotbah dari Lukas 14:16-24 tentang perumpamaan orang-orang yang berdalih. Ia berbicara tentang perjamuan kawin antara mempelai perempuan dan Mempelai Laki-laki. Setelah itu Moody jatuh sakit dan tidak bisa melanjutkan pelayanannya. ${ }^{30}$

Kemudian ia pulang kembali ke kotanya Northfield untuk beristirahat. Di kotanya inilah Moody menghembuskan nafasnya yang terakhir dengan membawa kedamaian surgawi pada tanggal 22 Desember 1899. Dunia dikejutkan oleh kematiannya karena tidak banyak yang mengetahui penyakitnya. Dia menorehkan kenangan manis bagi keluarganya dan setiap orang yang pernah dilayaninya. Sesaat sebelum abad baru dimulai, jantung lemahnya memaksa Moody untuk segera mengakhiri perjalanan pengkhotbahannya. Pada usia enam puluh dua tahun, dia meninggal, tepatnya pada tanggal 22 Desember 1899, di rumahnya di Northfield, tempat dia dikuburkan. ${ }^{31}$

\section{Kehidupan Rohani Sang Tokoh bersama Keluarganya}

Dari abad ke abad, banyak hamba Allah yang besar bergumul dengan keseimbangan kehidupan rumah tangga mereka. Seringkali hamba Tuhan menghadapi anak-anak mereka yang memberontak atau suka berfoya-foya. Namun, kehidupan Moody berkenaan dengan hal ini sama kokohnya seperti pekerjaan penginjilannya yang spektakuler. Fitt menulis: ${ }^{32}$

"Tidak ada kehidupan pribadi seseorang bila diperhatikan secara seksama lebih baik daripada D.L. Moody, apakah Anda melihatnya dari perannya sebagai orangtua, tetangga, atau teman. Dalam segala sesuatu ia adalah orang Kristen sejati, laki-laki sejati."

\footnotetext{
29 Ibid, 175

30 Ibid, 175; Moody, 23-24.

31 Ibid

32 Moody, 19-20; A.P. Fitt. The Life of D.L. Moody.
} 
Pernikahannya dengan Emma diberkati. Walaupun awalnya, keputusan Moody yang tiba-tiba tidak lagi meneruskan bisnis sepatunya dan tidak lagi peduli soal mencari uang menjadi pilihan sulit bagi Emma Revell, yang saat itu baru saja bertunangan dengan Moody. Menikah dengan Moody sekarang dapat berarti hidup dalam kemiskinan. Namun, ia tidak hanya mencintai Moody, tetapi juga mempunyai beban yang sama untuk jiwa-jiwa yang terhilang. Jadi, ia mengajar di sekolah selama tiga tahun pertunangan mereka, dan mereka menikah pada tahun 1862 , pada masa pergolakan Perang Saudara. Itu adalah pernikahan yang sempurna bagi Moody karena mempunyai istri yang menjadi ibu yang hebat bagi anak-anaknya, dan penolong yang tidak kenal lelah dalam pelayanannya. ${ }^{33}$

Moody dan Emma bersatu dalam pekerjaan Tuhan dan keluarga. Emma bertanggung jawab dalam perannya sebagai ibu yang membesarkan tiga anaknya: Emma, William, dan Paul. Ia juga berperan sebagai sekretaris pribadi selama bertahun-tahun bekerja di Chicago, Eropa dan seluruh Amerika. Bilamana mungkin, Moody akan membawa seluruh keluarganyadalam setiap kebaktian penginjilan. Mereka bersamanya dalam seluruh rangkaian kebaktian penginjilan di Eropa, dan banyak kebaktian penginjilan di Amerika. ${ }^{34}$

Anak-anaknya mempunyai kenangan yang indah tentang ayah mereka dan "otot kekristenannya'. Ketika dewasa, Paul anaknya, mengingat ayahnya sebagai "orang terbesar dan terbaik yang pernah saya kenal". ${ }^{35}$ Demikian juga dengan anaknya yang lain yaitu William R. Moody dalam pengantarnya dalam buku "The Life of Dwight L. Moody", suatu biografi ayahnya. Ia berkata" Ayahnya hidup seata-mata untuk memuliakan Tuhan untuk penyebaran Injil Yesus Kristus dan merupakan doa yang sungguh-sungguh dari keluarga yang menjadi tujuan hidup yang dapat tetap dipelihara". ${ }^{36}$

Bila berada di rumah mereka di Northfield, Moody melepaskan pernak-perniknya sebagai penginjil, khususnya pakaian hitam tebal yang biasa dipakainya. Ia mengenakan pakaian petani yang nyaman dan mengesampingkan urusan kebaktian selama masa itu. Ia terkenal di

${ }^{33}$ Ibid, 9.

${ }^{34} \mathrm{Ibid}, 20$.

${ }^{35}$ Moody, 20.

${ }^{36}$ William R. Moody. The Life of Dwight L. Moody. East Northfield: Official Authorized Edition, 1900, 7 diakses 25 November 2011 dari http:/www.ntslibrary.com/PDF\%20Books/Life\%2520of\%2520Moody.pdf 
kotanya, bukan sebagai penginjil kenamaan, melainkan orang yang murah hati, jujur dan menyenangkan yang membuka rumahnya untuk siapa saja, dan membuat mereka terhibur dengan cerita-cerita indah. ${ }^{37}$

Moody adalah seorang pria dengan sekumpulan hal yang tampak bertentangan. Tanpa mengenyam cukup pendidikan, dia berhasil mendirikan tiga sekolah. Dia berkhotbah bagi ribuan orang di seluruh dunia, tetapi dia diingat oleh anak-anaknya sebagai ayah yang tetap memerhatikan keluarga. Dia berpelukan dengan negarawan, namun memiliki perhatian khusus pada para pemuda dan kuda-kuda. Dia senang membuat lelucon sederhana; saat di rumah dia memakai "pakaian tidak layak pakai", menunggang kuda, dan mengendarai kereta dengan kecepatan sangat berbahaya mengelilingi lahannya di Northfield. Salah seorang putranya berkata bahwa dia adalah "Peter Pan gemuk dan berjanggut, seorang anak laki-laki yang tidak pernah sungguh-sungguh menjadi dewasa. ${ }^{138}$

Pada tahun 1876, dia membeli sebidang lahan di Northfield, Massachusetts, tempat ibunya masih tinggal. Di tempat ini dia menghabiskan bulan-bulan musim panas, menikmati waktu bersama anaknya di daerah yang waktunya itu disebut anaknya dan kemudian cucu-cucunya. Walaupun Moody hanya mengenyam sedikit pendidikan, dia berhasil mendirikan dua sekolah di daerah ini: Sekolah Seminari Putri Northfield (Northfield Seminary) dan Sekolah Putra Gunung Hermon (Mount Hermon School). ${ }^{39}$

Dwight L. Moody adalah seorang tokoh yang penuh dengan kuasa dan mempertahankan kebenaran yang besar. "Roh Tuhan ALLAH ada padaku, oleh karena TUHAN telah mengurapi aku; Ia telah mengutus aku untuk menyampaikan kabar baik". D.L. Moody adalah seorang yang sederhana, tulus, tidak mementingkan diri sendiri, setia dalam imannya kepada Kristus dan mempunyai satu karunia istimewa, yaitu menyajikan Kabar BAik yang mulia itu dengan cara yang dapat dimengerti oleh semua orang. Kehidupan dan pelayanan Moody terus mengundang orang berdosa untuk dating kepada Kristus. Ia melihat setiap orang, betapun jauhnya dari Allah, sebagai calon anak Raja, dan sebagai satu kesempatan dari kekekalan. Inilah kekuatan yang mendorong Moody untuk menjadi salah seorang penginjil terbesar di dunia. "Saya tidak percaya ada berita yang lebih baik untuk telinga manusia yang fana, selain daripada berita Injil". Walaupun ia orang sederhana dan mempunyai pendidikan formal yang rendah, kerinduannya akan keselamatan orang-orang yang terhilang bagaikan nyala api yang terang

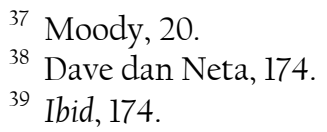


seperti kasihnya yang tulus kepada Allah dan sesamanya. "Yang paling menyenangkan dalam hidup ini adalah memenangkan jiwa bagi Kristus". 40

\section{Falsafah Pelayanan D.L. Moody}

Rahasia sesungguhnya mengapa D.L. Moody dipakai oleh Yang Maha Kuasa dapat ditemukan dalam Alkitab Mazmur 62:12, "Satu kali Allah berfirman, dua hal yang aku dengar: bahwa kuasa dari Allah asalnya". Kita akan mempelajari falsafah pelayanan Moody berdasarkan R.A. Torrey melalui tujuh rahasia mengapa Allah memakai D.L. Moody dengan luar biasa pada masanya. ${ }^{41}$

Rahasia pertama yang menunjukkan bahwa Allah memakai D.L. Moody adalah bahwa ia adalah seorang pria yang sepenuhnya berserah kepada Tuhan. ${ }^{42}$ Setiap berat dari tubuhnya adalah milik Allah, dan segala yang ia miliki, seluruhnya milik Allah. Moody bukanlah manusia sempurna, dia juga memiliki kelemahan pada karakternya. R.A. Torrey telah mengenal laki-laki yang sempurna dalam arti di mana Alkitab memerintahkan kita untuk menjadi sempurna yaitu sepenuhnya milik Allah, dari Dia dan untuk Dia, sepenuhnya menyerah kepada Allah, bukan kehendak Moody, akan tetapi kehendak Tuhan. Moody berpaling kepada Torrey dengan terus terang dan baik hati berkata untuk membela posisinya sendiri: "Torrey, jika saya percaya bahwa Allah ingin saya untuk melompat keluar dari jendela itu, aku akan melompat." Jika dia berpikir Tuhan ingin dia untuk melakukan sesuatu, ia akan melakukannya. Moody sungguh-sungguh berserah kepada Allah. Ia milik Allah sepenuhnya, tanpa syarat,tanpa kualitas, seluruhnya kepada Allah. ${ }^{43}$

Rahasia kedua, kekuatan besar yang ditunjukkan dalam kehidupan Moody adalah adalah seorang pria yang senang berdoa. Torrey dan Moody sering berkumpul sampai jam tiga atau empat pagi, berseru kepada Allah, hanya karena Moody mendesak mereka untuk menunggu Allah sampai kami menerima berkat-Nya. Banyak orang yang hidup dan karakternya telah diubahkan dan telah melakukan hal-hal besar di berbagai tempat karena malam-malam doa itu. Moody juga menghadapi banyak tantangan dalam pelayanannya, tetapi ia selalu tahu cara untuk

\footnotetext{
${ }^{40}$ Moody, vii-viii.

${ }^{41}$ Rueben Archer Torrey. Why God Used D.L. Moody. The bible Institute Colportage Association, 1923 diakses 25 November 2011 dari http://www.whatsaiththescripture.com/Voice/Why.God.Used.D.L.Moody.html

${ }^{42}$ Moody, ix.

${ }^{43}$ Torrey. Why God Used D.L. Moody.
} 
mengatasi semua kesulitan itu. Dia tahu dan percaya di kedalaman dari jiwanya yaitu "tidak terlalu sulit bagi Tuhan" dan doa yang bisa melakukan apa pun yang Tuhan dapat lakukan. ${ }^{44}$

Pada satu kesempatan Moody di Chicago berdoa kepada Tuhan katanya, "Saya perlu dua puluh ribu dolar untuk pekerjaan saya". Dan Tuhan mendengar doa itu. Uang itu sedemikian rupa Moody dapatkan, sehingga jelas bahwa itu datang dari Allah di dalam jawaban langsung atas doa. Moody adalah seorang yang percaya pada Allah yang menjawab doa, dan tidak hanya percaya kepada-Nya secara teoritis, tetapi percaya kepada-Nya dengan cara yang praktis. Dia adalah seorang pria yang setiap bertemu kesulitan selalu berdiri di jalan-Nya dengan doa. Semua yang dia lakukan itu didukung oleh doa, dan dalam segala hal, ketergantungan utamanya adalah kepada Allah. ${ }^{45}$

Rahasia ketiga Moody atau alasan ketiga mengapa Allah memakai D.L. Moody, karena dia adalah seorang murid yang mempelajari Alkitab secara mendalam sekaligus praktis. Anda boleh berbicara tentang kuasa. Namun, bila Anda mengabaikan satu Buku yang diberikan Allah kepada Anda sebagai sarana yang melaluinya. Dia menanamkan kuasa-Nya, Anda tidak akan mempunyai kuasa itu. Anda dapat membaca banyak buku dan pergi ke banyak pertemuan dan Anda mungkin memiliki semua pertemuan doa malam Anda untuk berdoa bagi kuasa Roh Kudus, maka Anda tidak akan memiliki kuasa-Nya kecuali jika Anda tetap konsisten dan memiliki hubungan dekat dengan Alkitab. Dan jika Anda pernah memiliki kuasa, dan Anda tidak dapat mempertahankannya kecuali dengan mempelajarinya sungguh-sungguh Alkitab setiap hari. Sembilan puluh sembilan dari seratus orang Kristen tidak bersungguh-sungguh mempelajari Alkitab. Oleh karena itu, mereka lemah padahal mereka seharusnya menjadi raksasa rohani, baik dalam kehidupan Kristen maupun pelayanan mereka. ${ }^{46}$

Saat ini sering dikatakan bahwa D.L. Moody bukanlah seorang mahasiswa atau murid. Dia bukan mahasiswa psikologi, dia bukan mahasiswa antropologi, bahkan ia bukan seorang mahasiswa teologi, dalam arti teknis tetapi dia adalah seorang mahasiswa, seorang murid yang mendalam dan praktis mempelajari Alkitab yang lebih bernilai daripada semua buku belajar lain di dunia. Setiap hari dalam hidupnya, Moody bangun sangat awal di pagi hari untuk mempelajari Firman Allah sampai akhir hidupnya. Dia akan mengatakan kepada Torrey, katanya, "Jika saya mau mendapatkan apapun dalam penelitiannya, saya harus

\footnotetext{
${ }^{44}$ Ibid.

${ }^{45}$ Ibid.

${ }^{46}$ Ibid.
} 
bangun sebelum orang-orang lain bangun", dan ia akan mengurung diri di sebuah ruangan terpencil di rumahnya sendirian dengan Allah dan Alkitabnya. Torrey menceritakan pengalamannya bersama Tuan Moody, ia berkata, "Ini sangat terlambat ketika aku tidur malam itu, tapi sangat pagi-pagi, sekitar pukul lima, aku mendengar ketukan lembut di pintu saya. Lalu aku mendengar bisik-bisik suara Tuan Moody: "Torrey, apakah Anda sudah bangun?" Saya tidak selalu bangun pada jam awal tapi kebetulan saya harus bangun pagi. Dia berkata, "Aku ingin kau pergi ke suatu tempat dengan saya," dan aku turun dengan dia. Kemudian saya menemukan bahwa dia sudah sampai satu atau dua jam di kamarnya mempelajari Firman Allah. Dapat dikatakan bahwa dia benar-benar murid Alkitab. ${ }^{47}$

Seseorang mempunyai "semangat tanpa pengetahuan", sementara yang lain mempunyai "pengetahuan tanpa semangat". Bila harus memilih maka Tuan Moody memilih yang pertama. Dengan Alkitab yang terbuka, tidak seorang pun yang tidak akan mengetahui kehendak dan tujuan Allah. Paulus berkata, "Segala tulisan yang diilhamkan Allah memang bermanfaat untuk mengajar, untuk menyatakan kesalahan, untuk memperbaiki kelakuan dan untuk mendidik orang dalam kebenaran. Dengan demikian tiap-tiap manusia kepunyaan Allah diperlengkapi untuk setiap perbuatan baik" (2 Timotius 3:16-17). ${ }^{48}$

Rahasia keempat mengapa Allah terus menerus dari tahun ke tahun memakai D.L. Moody karena ia seorang yang rendah hati. Torrey berpikir D.L. Moody adalah pria bersahaja yang pernah dia kenal di sepanjang hidupnya. Ia suka mengutip kata-kata lain, "Faith gets the most; love works the most; but humility keeps the most ". ${ }^{49}$

Seperti Torrey telah katakan bahwa dia adalah orang paling sederhana yang pernah saya kenal, yaitu orang yang paling rendah hati ketika kita mengingat hal-hal besar yang telah ia lakukan, dan pujian yang dilimpahkan kepadanya. Betapa ia mencintai untuk menempatkan dirinya di belakang dan menempatkan orang lain di depan. Seberapa sering ia akan berdiri di platform dengan beberapa rekannya sedikit duduk di belakangnya dan ketika ia berbicara ia akan berkata: "Ada orang yang lebih baik yang datang setelah aku". Tapi dia benar-benar percaya bahwa orang lain yang datang setelah dia benar-benar lebih baik daripada dia itu. Dalam hatinya yang terdalam dia terus merendahkan dirinya sendiri, dan meninggikan orang lain ..$^{50}$

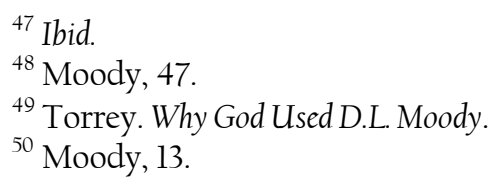


Oleh karena kerendahan hatinya untuk memulai menjalankan hidup hemat, kerja keras, dan ikatan keluarga yang erat, Moody berhasil mendekati rakyat jelata dan selalu memiliki rasa kasihan pada kaum miskin. Tetapi dia pun terkenal di antara pengabar Injil kaya yang membantu pelayanannya. Moody juga memiliki sikap yang tulus dalam mengajar anak-anak di kelasnya. Ia memiliki prinsip bahwa semakin buruk sikap anak itu, semakin banyak alasan untuk tidak mengeluarkannya. Oleh karena itu, tidak ada orang yang pernah dikeluarkan dari kelas. Dan murid-muridnya juga menyayanginya. ${ }^{51}$

Moody telah mengunjungi Eropa pada tahun 1867 ketika dokter istrinya mendesaknya untuk melakukan perjalanan lewat laut untuk menyembuhkan batuk kronis yang diderita istrinya. Sebenarnya Moody tidak tertarik pada sejarah Eropa, namun ia sangat ingin bertemu dengan C.H. Spurgeon dan George Mueller, yang sudah berpengaruh besar pada penginjil Amerika ini. Moody telah belajar banyak dari kotbah-khotbah Spurgeon, dan sangat mengagumi iman Mueller yang mengelola pantipanti asuhannya tanpa meminta uang dari siapa pun. Sebenarnya Moody belum dikenal di Eropa pada perjalanan kali itu. Namun, dengan cepat ia terkenal karena khotbahnya yang sederhana dan gayanya yang merendahkan diri yang tidak mau disebut 'pendeta' hanya D.L. Moody, seorang pekerja Sekolah Sabat. ${ }^{52}$

Rahasia kelima D.L. Moody adalah ia benar-benar tidak cinta uang. Artinya ia terbebas dari cinta uang. Tuan Moody mungkin telah menjadi orang kaya, tapi uang tidak menjadi daya tarik baginya. Dia mengasihi pekerjaan-Nya untuk mengumpulkan uang untuk pekerjaan Tuhan, tetapi ia menolak untuk mengumpulkan uang untuk dirinya sendiri. Uang tidak pernah menjadi masalah bagi Moody. Sesudah diutus oleh Allah, ia kehilangan minatnya dalam mencari dan membelanjakan uang. Seleranya sederhana, dan pikiran serta hatinya selalu pada pekerjaan Bapa. ${ }^{53}$

New York Tribune menulis tentang kebaktian-kebaktian penginjilan di Inggris ini. Ini merupakan pujian dari media sekuler, bahkan pada zaman itu: $:^{54}$

"Hanya ada satu pendapat mengenai ketulusan mereka, Moody dan Sankey. Mereka bukan pengeruk uang, mereka bukang tukang obat. Orang-orang konservatif yang mencela pekerjaan dan cara kerja mereka, telah mengamati mereka selama berbulan-bulan, dan

\footnotetext{
${ }^{51}$ Ibid, 7.

${ }^{52}$ Moody, 13.

${ }^{53}$ Ibid.

${ }^{54}$ Ibid.
} 
tidak dapat menemukan satu pun motivasi mereka yang tidak tulus".

Cinta akan uang adalah titik dimana banyak penginjil membuat kapal karam, dan pekerjaan yang besar akan berakhir sebelum waktunya. Cinta uang telah membuat pekerjaan penginjilan menjadi celaan orang, lebih daripada penyebab yang lain. Lain halnya dengan pribadi Moody, dimana jutaan dollar lewat ditangan Moody, tetapi uang itu mengalir terus; uang itu tidak menempel di jari-jarinya. Uang yang diperolehnya digunakan untuk pekerjaan Tuhan di gereja, sekolah, kebaktian kebangunan rohani, traktat dan kegiatan lain yang dirasanya bak. Dengan cara ini, ia seperti Mueller, tokoh yang sangat dikaguminya. ${ }^{55}$

Rahasia keenam, mengapa Allah memakai D.L. Moody karena semangat menyelamatkan orang yang terhilang untuk diselamatkan. Tuan Moody membuat resolusi, tak lama setelah ia sendiri diselamatkan, maka ia tidak akan membiarkan dua puluh empat jam berlalu tanpa berbicara tentang Kristus kepada sekurang-kurangya satu orang. Hal yang luar biasa yang dilakukan Moody walaupun sangat sibuk apabila sehari tidak berbicara tentang Kristus maka kadang-kadang ia akan keluar dari tempat tidurnya, berpakaian, dan pergi keluar serta berbicara dengan seseorang tentang keselamatan jiwanya dan dia tidak akan membiarkan jiwa berlalu saja tanpa memiliki kepastian keselamatan yang menjadi kebutuhan manusia dan Juruselamat yang bisa memenuhi kebutuhan itu. ${ }^{56}$

Moody berpendapat lebih baik semangat tanpa pengetahuan daripada memiliki pengetahuan tentang Alkitab tetapi tidak memiliki semangat menginjil. Manusia seperti itu sangat berpengalaman dalam kebenaran Alkitab tetapi memiliki semangat begitu sedikit untuk mengarahkan satu jiwa kepada Kristus dalam satu tahun. ${ }^{57}$ Moody berkata dalam bukunya Secret Power, "Saya tidak bersimpati kepada orang-orang yang mencoba membatasi keselamatan dari Allah hanya untuk beberapa orang tertentu. Saya percaya bahwa Kristus telah mati untuk semua orang yang akan datang. Saya telah menerima banyak surat yang menyalahkan saya, dan mengatakan bahwa saya pasti tidak percaya pada doktrin pemilihan (predestinasi). Saya percaya bahwa Allah telah menentukan dari semula orang-orangyang akan diselamatkan. Namun, saya tidak perlu mengkhotbahkan doktrin itu ke seluruh dunia. Dunia tidak

${ }^{55} \mathrm{Ibid}, 18-19$.

${ }^{56}$ Torrey. Why God Used D.L. Moody.

${ }^{57}$ Ibid. 
memerlukan berita tentang pemilihan itu; yang diperlukan dunia adalah undangan, "Barangsiapa haus, baiklah ia datang kepada-Ku dan minum". Itulah berita untuk orang berdosa. Saya diutus untuk memberitakan Injil kepada semua orang. ${ }^{58}$

Suatu malam Tuan Moody di tempat tidur ketika ia mendengar suara keras di depan pintu rumahnya. Dia melompat dari tempat tidur dan bergegas ke pintu. Dia berpikir rumah itu terbakar. Dia berpikir pria itu akan mendobrak pintu. Dia membuka pintu dan di sana berdiri orang itu. Dia berkata: "Tuan Moody, saya belum pernah tidur nyenyak sejak malam itu Anda berbicara kepada saya di bawah tiang lampu, dan aku telah datang pada larut jam malam dan saya berpikir wajar bagi Anda untuk memberitahu saya apa yang harus saya lakukan untuk diselamatkan". Tuan Moody itu membawanya masuk dan mengatakan kepadanya apa yang harus dilakukan untuk diselamatkan. Lalu ia menerima Kristus, dan ketika Perang Sipil pecah, ia pergi ke baris depan untuk berperang dan meletakkan hidupnya berjuang untuk negaranya. ${ }^{59}$

Suatu saat Moody pergi ke Milwaukee, dan ia duduk di kursi dimana ia telah memilih seorang yang duduk disampingnya. Tuan Moody segera mulai berbicara dengan dia. "Di mana Anda akan pergi?" Tuan Moody bertanya. Ketika mengatakan nama kota, ia berkata: "Kami akan segera berada di sana, apakah Anda sudah diselamatkan.?" Pria itu berkata bahwa ia belum diselamatkan. Lalu Tuan Moody mengeluarkan Alkitabnya selama di kereta itu, ia menunjukkan kepadanya jalan keselamatan. Lalu ia berkata: "Sekarang, Anda harus menerima Kristus." Pria itu melakukannya; dia bertobat di atas kereta api. ${ }^{60}$

Semangat yang membakar D.L. Moody bagi jiwa-jiwa bukan untuk nantinya mereka yang akan membantu dia dalam membangun karyanya di sini atau di tempat lain; cintanya bagi jiwa-jiwa tidak mengenal batasan kelas. Dia tidak membedakan orang, itu mungkin seorang bangsawan atau pejabat atau mungkin seorang anak yang bodoh di jalan, bagi dia ada jiwa untuk diselamatkan dan ia melakukan apa yang ada dalam kekuasaan-Nya untuk menyelamatkan jiwa itu. Moody sangat giat bagi Allah. Ia bukan sekadar 'bekerja', ia juga selalu menarik orangorang untuk bekerja bagi keselamatan orang lain. ${ }^{61}$

Rahasia ketujuh, mengapa Allah memakai D.L. Moody bahwa dia diperlengkapi kuasa dari tempat tinggi, sangat jelas dan pasti yaitu baptisan dengan Roh Kudus. Moody tahu bahwa ia telah mengalami "baptisan

\footnotetext{
${ }^{58}$ Moody, viii. Pengatar D.L. Moody dalam bukunya Secret Power.

${ }^{59}$ Torrey. Why God Used D.L. Moody.

${ }^{60}$ Ibid.

${ }^{61}$ Ibid.
} 
dengan Roh Kudus", dan dia tidak ragu tentang itu. Roh Kudus turun memenuhi jiwanya dengan sukacita sedemikian rupa sehingga ia harus meminta Allah menahan tangan-Nya, kalau tidak ia akan mati di tempat itu karena terlalu bersukacita. "Tetapi kamu akan menerima kuasa, kalau Roh Kudus turun ke atas kamu, dan kamu akam menjadi saksi-Ku di Yerusalem dan di seluruh Yudea dan Samaria dan sampai ke ujung bumi" (Kisah Para Rasul 1:8). ${ }^{62}$

Pada suatu pertemuan dimana ketika kesaksian sudah berakhir, Tuan Moody berkata: "laki-laki muda, saya tidak bisa melihat alasan mengapa kita tidak harus berlutut di sini sekarang dan meminta Tuhan bahwa Roh Kudus dapat turun atas kita sama seperti Roh Kudus turun ke atas para Rasul pada hari Pentakosta. Mereka berdoa di Northfield selama sepuluh hari, dan sesuatu terjadi karena belas kasihan dan kasih karunia dan kuasa Allah, bahwa Roh Kudus turun atas mereka. ${ }^{63}$

Dalam 1 Yohanes 5:7, tertulis: "Sebab ada tiga yang memberi kesaksian di dalam sorga: Bapa, Firman dan Roh Kudus; dan ketiganya adalah satu". Moody percaya bahwa Roh Kudus mempunyai kuasa kreatif yang ajaib. Di atas semua hukum alam, tetapi selaras dengan hukum itu, penciptaan, pemeliharaan, pemerintahan Allah, dan pembangunan Gereja Allah dipimpin oleh Roh Allah. ${ }^{64}$ Dalam buku Secret Power, mengungkapkan kuasa di balik "nyala api"ini, kuasa ilahi ini, yakni pekerjaan Roh Kudusdi hati manusia. Ia percaya bahwa kuasa ini diterima dari Allah ketika kita sepenuhnya mengosongkan diri dan siap melayani kehendak Allah. ${ }^{65}$

\section{PENUTUP}

\section{Refleksi Pribadi tentang Arti Pelayanan}

Moody percaya bahwa kuasa Roh Kudus telah terlalu lama diabaikan, seolah-olah itu hal yang rumit. Ia menulis, "Akibatnya tidak ada kuasa dalam kesaksian dan pelayanan. Bila kita ingin bekerja, "bukan sekedar memukul angin', melainkan pelayanan yang mempunyai tujuan yang jelas, kita harus mempunyai kuasa ini dari tempat tinggi. Tanpa kuasa ini, pelayanan kita menjadi pelayanan membosankan. Dengan kuasa ini, pelayanan itu menjadi menyenangkan dan berkat bagi banyak orang. Inilah doa saya."

\footnotetext{
${ }^{62}$ Moody,x; Torrey. Why God Used D.L. Moody.

${ }^{63}$ Torrey. Why God Used D.L. Moody

${ }^{64}$ Moody, 50,52.

${ }^{65} \mathrm{Ibid}$, viii.
} 
"Tanpa jiwa, ketaatan terhadap ritualisme yang memberi hidup dan diilhami Allah pun sama tidak berharganya seperti mayat yang digerakkan". Kutipan Moody ini didasarkan pada: "Apa jadinya jiwa kita tanpa kasih karunia-Nya? Atau bagaimana jadinya gereja tanpa Dia”. Kita membutuhkan kuasa Roh Kudus dalam pelayanan karena semangat tanpa pengetahuan dengan kuasa Roh Kudus lebih baik daripada pengetahuan Alkitab tanpa semangat. ${ }^{66}$ Roh Kudus memenuhi kita untuk memberitakan Kabar Baik kepada semua orang yaitu jiwa-jiwa yang terhilang.

Roh Kudus yang turun dan memberi kuasa untuk menjadi saksi dan melaksanakan Amanat Agung untuk menjadikan semua orang murid-Nya (Kisah Para Rasul 1:8;Matius 28:18-20). Sebagaiman Roh Kudus turun atas Yesus Kristus untuk melakukan kehendak Bapa (Yoh. 4:34). Roh Kudus yang memberi semangat pelayanan walaupun badan sudah menjadi lemah dan tua tetapi api itu tetap menyala. Stephen Tong berkata kepada pemuda-pemudi, "Setelah saya mendengan pujian Bapa tentang Anak-Nya, pelayanan Anak menjadi contoh dan bersedia jikalau Tuhan hendak memakai saya. Di sini aku Tuhan, utuslah aku. Aku mau dipakai untuk Tuhan". ${ }^{67}$

Arti pelayanan bagi penulis adalah pelayanan yang dipimpin oleh Roh Kudus untuk memuliakan Bapa dengan melakukan kehendak-Nya. "Datanglah Kerajaan-Mu dan jadilah kehendak-Mu". Semua yang dilakukan gereja atau setiap pelayanan dalam bidang apapun, seharusnya untuk memuliakan Allah, bukan semata-mata untuk keunggulan pelayan dan kelompoknya, atau untuk mengeluarkan masyarakat yang dilayani, atau untuk membebaskan suatu daerah dari cengkraman iblis atau untuk keberhasilan kelompok tertentu. Hal-hal itu semuanya adalah yang tidak utama. Apapun yang dilakukan melalui rumusan filsafat pelayanan adalah untuk memuliakan Tuhan secara terus-menerus dan langsung diarahkan kepada Dia. Orang Kristen sebenarnya sedang melayani Allah melalui cara melayani manusia. ${ }^{68}$

Setiap pelayan Tuhan memiliki hati hamba. Setiap filsafat pelayanan harus menyadari bahwa kita menghambakan diri kepada Allah, bukan pada: uang, kemasyuran, kehormatan diri, atau orang penting. Tuhan sendiri yang memanggil dan memilih kita melalui cara-Nya sendiri, untuk memakai kita sebagai alat-Nya semata. Namun demikian, kita juga harus melayani manusia dan dunia ini, tanpa harus menghambakan

\footnotetext{
${ }^{66}$ Moody, 49.

${ }^{67}$ Stephen Tong. Teladan Pelayanan Kristus. Surabaya: Majalah MOMENTUM No. 44- Oktober 2000,17.

${ }^{68}$ Togardo Siburian. Pengembangan Suatu Filsafat Pelayanan Dalam Rangka Visi dan Misi Kristen. Jurnal STULOS 7/1 (April 2008), 25.
} 
diri kepada manusia atau dunia. Pelayanan kepada manusia tidak boleh diabaikan dalam melayani Tuhan. Kita dapat melayani Tuhan, yang tidak terlihat tersebut hanya melalui melayani sesama yang terlihat. ${ }^{69}$

Keberhasilan yang terlihat adalah anugerah Tuhan saja. Karena sebenarnya ada keberhasilan pelayanan tidak dapat dilihat secara eksternal, yaitu kesetiaan internal pada panggilan Tuhan. Bagi orang yang negatif terhadap pemikiran strategis dan sistematis dalam pelayanan, hal ini menjadi alasan membatasi kuasa Roh Kudus. Tetapi sebaiknya mengingat kembali bahwa filsafat pelayanan tidak dirumuskan untuk menyingkirkan kuasa Roh Kudus, tetapi mempersilahkan Roh Kudus bekerja melalui kita. ${ }^{70}$

\section{DAFTAR PUSTAKA}

Alkitab. Jakarta: Lembaga Alkitab Indonesia, 2004.

Curtis, A. Kenneth et al. 100 Peristiwa Penting dalam Sejarah Kristen. Jakarta: BPK Gunung Mulia, 2009.

Dave dan Neta Jackson. Bahaya di Ujung Tali Akrobat. Batam: Gospel Press, 2004 diakses 25 November 2011 dari http://biokristi.sabda.org/dwight___moody

Fitt,A.P. Riwayat Hidup D.L. Moody. Surabaya:Christian Literature Crusade, 2008 diakses 25 November 2011 dari http://www.sabda.org/misi/tokoh_isi.php?id=7

Moody, D.L. Secret of Power. Yogyakarta: Penerbit ANDI, 2010.

Moody, William R. The Life of Dwight L. Moody. Official Authorized Edition, 1900 diakses 25 November 2011 dari http://www.ntslibrary.com/PDF\%20Books/Life\%2520of\%2520Moo dy.pdf

Siburian, Togardo. Pengembangan Suatu Filsafat Pelayanan Dalam Rangka Visi dan Misi Kristen. Jurnal STULOS 7/1 (April 2008).

Torrey, R.A. Why God Used D.L. Moody.The bible Institute Colportage Associ., 1923 diakses 25 November 2011 dari http://www.whatsaiththescripture.com/Voice/Why.God.Used.D.L. Moody.html

Tong, Stephen. Teladan Pelayanan Kristus. Surabaya:Majalah MOMENTUM No. 44- Oktober 2000 diakses 25 November 2011 dari http://www.thisisreformed.org/artikel/plynkrs.html

\footnotetext{
${ }^{69}$ Ibid.

${ }^{70} \mathrm{Ibid}, 36$.
} 